\title{
Relationship Between Gestational Weight Gain and Amount of Postpartum Bleeding
}

\author{
Gestasyonel Kilo Alımı ile Postpartum Kanama Miktarı Arasındaki İlişki

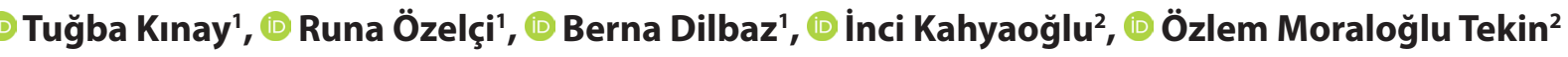 \\ 'Department of Obstetrics and Gynecology, University of Health Sciences Etlik Zübeyde Hanım Women's Health Training and \\ Research Hospital, Ankara, Turkey \\ ${ }^{2}$ Department of Obstetrics and Gynecology, Ankara City Hospital, Ankara, Turkey
}

\begin{abstract}
Aim: To evaluate the effect of gestational weight gain on the amount of postpartum bleeding.

Material and Method: Medical records of women with low-risk singleton pregnancies who delivered vaginally at 37 weeks of gestation or beyond, between May 1 and November 1 2018, at a tertiary referral center were reviewed in the observational study. Demographic and clinical characteristics were obtained from the medical records. The relationship between the increased rate in BMI during pregnancy and amount of blood loss in the postpartum first hour was evaluated.

Results: A total of 411 women was included in the study. In the study population, the mean blood loss was $57.3 \pm 43.9$ $\mathrm{ml}$ in the 3rd stage of labor and $113.2 \pm 76.9 \mathrm{ml}$ in the postpartum first hour. No correlation was found between the increase in BMI during pregnancy and blood loss during the 3rd stage of labor $(r=0.006)$ and postpartum first hour $(r=0.037)$. Nulliparity, history of postpartum hemorrhage in previous pregnancy, premature rupture of membranes, and episiotomy were found to be risk factors for increased postpartum blood loss during the 1st hour $(p<0.05)$.

Conclusion: Increase in BMI was not related with the amount of postpartum bleeding in women with low-risk pregnancy who had a vaginal delivery.
\end{abstract}

Keywords: Body mass index, episiotomy, gestational weight gain, nulliparity, postpartum hemorrhage
Öz

Amaç: Gebelikte kilo alımının postpartum kanama miktarına etkisini değerlendirmek.

Gereç ve Yöntem: Gözlemsel çalışmada 1 Mayıs-1 Kasım 2018 tarihleri arasında üçüncü basamak bir merkezde 37. gebelik haftasında veya daha sonrasında vajinal doğum yapan düşük riskli gebeliği bulunan kadınların tıbbi kayıtları incelendi. Olguların demografik ve klinik özellikleri tıbbi kayıtlardan elde edildi. Gebelikte Vücut Kitle Indeksindeki (VKI) artış oranı ile postpartum birinci saatteki kan kaybı miktarı arasındaki ilişki değerlendirildi.

Bulgular: Çalışmaya toplam 411 kadın dahil edildi. Çalışma grubunda ortalama kan kaybı doğumun 3. evresinde 57,3 $\pm 43,9$ $\mathrm{ml}$ ve postpartum birinci saatte 113,2 $\pm 76,9 \mathrm{ml}$ idi. Gebelik sırasındaki VKi'deki artış oranı ile doğumun 3. evresindeki $(r=0,006)$ ve postpartum birinci saatteki kanama miktarı $(r=0,037)$ arasında ilişki bulunmadı. Nulliparite, önceki gebelikte postpartum kanama öyküsü, erken membran rüptürü ve epizyotomi 1. saatte postpartum kan kaybını artıran risk faktörleri olarak bulundu $(p<0,05)$.

Sonuç: Vücut kitle indeksindeki artış, vajinal doğum yapan düşük riskli gebeliği olan kadınlarda postpartum kanama miktarıyla ilişkili bulunmadı.

Anahtar Kelimeler: Epizyotomi, gestasyonel kilo alımı, nulliparite, postpartum kanama, vücut kitle indeksi

Corresponding (illetişim): Tuğba Kınay, Department of Obstetrics and Gynecology, University of Health Sciences Etlik Zübeyde Hanım Women's Health Training and Research Hospital, Ankara, Turkey

E-mail (E-posta): tkinay@hotmail.com

Received (Geliş Tarihi): 22.10.2019 Accepted (Kabul Tarihi): 07.05.2020 


\section{INTRODUCTION}

Postpartum hemorrhage is a major cause of maternal morbidity worldwide and remains the leading preventable cause of maternal mortality, especially in low-income countries. Advanced maternal age, multiple pregnancies, polyhydramnios, operative or cesarean delivery, placental adhesion anomalies, preeclampsia, maternal anemia, and chorioamnionitis are well-known risk factors for postpartum hemorrhage. ${ }^{[1-4]}$ However, in the past two decades, the increase in the incidence of postpartum hemorrhage in high-income countries suggests that all risk factors have not yet been demonstrated. ${ }^{[5,6]}$ Recent studies have shown that obesity is a risk factor for postpartum hemorrhage. ${ }^{[1,7,8]}$ According to the World Health Organization (WHO), a body mass index (BMI) $>40 \mathrm{~kg} / \mathrm{m}^{2}$ is considered to be Class III obesity ${ }^{[9]}$ Blomberg ${ }^{[10]}$ reported a twofold increased risk of postpartum hemorrhage in Class III obese women.

Obesity is one of the most important global health problems, affecting $13 \%$ of the population worldwide. ${ }^{[1]}$ Pregnant women are prone to obesity due to excessive weight gain during pregnancy. Maternal obesity and excessive gestational weight gain are related to poor obstetric outcomes such as gestational hypertension, diabetes, and increased risk of cesarean delivery. ${ }^{[12]}$ On the other hand, previous studies reporting the relationship between gestational weight gain and postpartum hemorrhage have had conflicting results. While Li et al. ${ }^{[13]}$ reported increased postpartum hemorrhage risk with the excessive gestational weight gain; no association between the postpartum hemorrhage and gestational weight gain was found in another study. ${ }^{[14]}$ In these reports, the amount of gestational weight gain $(\mathrm{kg})$ was the primary parameter and the change in BMI during pregnancy was not taken into consideration. However, BMI is the most widely used tool for assessing the severity of obesity. In our literature search, the data on the effect of BMl change on the amount of postpartum bleeding are scarce. The aim of the present study is to evaluate the relationship between $\mathrm{BMI}$ increase rate during pregnancy and the amount of postpartum blood loss.

\section{MATERIAL AND METHOD}

Women with low-risk singleton pregnancies who had a vaginal delivery at 37 weeks of gestation or beyond, between May 1 and November 1, 2018, at University of Health Sciences Etlik Zubeyde Hanim Women's Health Training and Research Hospital were included in the observational study, which was approved by the Etlik Zubeyde Hanim Women's Health Training and Research Hospital Ethical Committee (2018/16). Written and signed informed consent was obtained from all participants. Patients with high-risk pregnancies including adolescent pregnancies (<18 years old), multiple pregnancies, polyhydramnios, hypertension, preeclampsia, diabetes mellitus, bleeding disorders, liver and kidney diseases, chorioamnionitis, adherent placenta, placental abruption,fetal demise, and having a history of previous cesarean delivery were excluded from the study.

Data of maternal demographics, antenatal care, and delivery were obtained from medical records of the women. Maternal age, height, pre-pregnancy maternal weight and weight at birth, gravidity, parity, gestational age at delivery, history of postpartum hemorrhage in previous pregnancies, and anticoagulant use were recorded. BMI was calculated by weight $(\mathrm{kg}) /$ height $^{2}\left(\mathrm{~m}^{2}\right)$. BMl increase rate was calculated by dividing the $\mathrm{BMI}$ difference between at birth $\left(\mathrm{BMI}_{2}\right)$ and pre-pregnancy $\left(\mathrm{BMI}_{1}\right)$ into pre-pregnancy $\mathrm{BMI}\left(\mathrm{BMI}_{1}\right)$. The following obstetric features were recorded: premature rupture of membranes, labor augmentation, durations of $1 \mathrm{st}$, 2nd, and 3rd stages of the labor, amount of blood loss during the 3rd stage and postpartum first hour, incidence of episiotomy, presence of birth canal lacerations and retained placenta, weight of the newborn, prepartum and postpartum hemoglobin levels, need for transfusion of blood products, and the duration of hospital stay.

The last menstrual period and ultrasonographic findings at $\leq 20$ weeks of gestation were used to determine the gestational age. Duration of the 1st stage of labor was defined as time from labor onset to complete cervical dilatation and effacement. The second stage of labor was defined as time from complete cervical dilatation and effacement to fetal expulsion. The third stage of labor was defined as time from fetal expulsion to placental expulsion. Oxytocin with the initial dose of $4 \mathrm{U} / \mathrm{min}$ (Synpitan Forte $5 \mathrm{IU} / \mathrm{ml}$, Deva, Istanbul, Turkey) was administered for labor augmentation in women with prolonged labor. Oxytocin dose was increased by 4U/ min as needed every 15 minutes. As a hospital policy, active management of the 3rd stage of labor with intravenous $10 \mathrm{IU}$ oxytocin in $500 \mathrm{ml}$ saline solution was carried out. Amount of vaginal bleeding was measured with a calibrated drape (Evergrand underbuttocks surgical drape, Zhejiang Mediunion Healthcare Group Co. Ltd, Zhangjiagang, Jiangsu, China) placed under the buttocks immediately after delivery of the newborn. The measurement of the amount of blood loss was started after the umbilical cord clamping to prevent amniotic fluid flow into the drape. The amount of blood loss from the time of umbilical cord clamping to the end of postpartum first hour was recorded.

The relationship between the increase in BMI during pregnancy and blood loss in the postpartum first hour was the primary outcome of the trial. The relationship between the amount of postpartum blood loss and the pre-pregnancy BMI, BMI at birth, durations of the stages of labor, and other risk factors for increased postpartum bleeding were the secondary outcomes.

SPSS version 17 (SPSS, Chicago, Illinois, USA) was used for statistical analysis.Descriptive statistics were presented as the mean and standard deviation or median (min-max) for continuous variables and number and percentage for categorical variables.Analysis of normality for continuous variables was performed using Kolmogorov-Smirnov and Shapiro-Wilk tests. Correlation coefficients and their significance of pre-pregnancy BMI, BMI at birth, BMI increase rate, durations of labor stages, and amount of blood loss parameters were calculated using the Pearson test. Continuous variables with normal distribution were analyzed using independent-samples t-test and without normal distribution were analyzed using the Mann-Whitney $U$ test. Analysis of categorical variables was performed by Chi-Square test. Statistical significance was defined as a $p$ value less than 0.05 . 


\section{RESULTS}

A total of 411 women met the inclusion criteria of the trial. The BMI of 25 women (6.1\%) was $<18.5 \mathrm{~kg} / \mathrm{m}^{2}$, of 228 women (55.4\%) was $18.5-24.9 \mathrm{~kg} / \mathrm{m}^{2}$, of 111 women (27\%) was 25$24.9 \mathrm{~kg} / \mathrm{m}^{2}$, of 36 women (8.8\%) was $30-34.9 \mathrm{~kg} / \mathrm{m}^{2}$, and of 11 women $(2.7 \%)$ was $35-39.9 \mathrm{~kg} / \mathrm{m}^{2}$. There was no woman with $\mathrm{BMI} \geq 40 \mathrm{~kg} / \mathrm{m}^{2}$. Maternal demographics, antenatal care, and delivery characteristics of the study population are shown in Table 1. One hundred and forty-nine women (36.3\%) were nulliparous, and 262 women (63.7\%) were multiparous. Mean BMl of women was $24.4 \pm 4.2 \mathrm{~kg} / \mathrm{m}^{2}\left(\min 15.9 \mathrm{~kg} / \mathrm{m}^{2}-\max 39.1\right.$ $\mathrm{kg} / \mathrm{m}^{2}$ ) at first trimester and $28.5 \pm 4.2 \mathrm{~kg} / \mathrm{m}^{2}$ (min $17.5 \mathrm{~kg}$ / $\mathrm{m}^{2}-\max 46.8 \mathrm{~kg} / \mathrm{m}^{2}$ ) at birth. Mean $\mathrm{BMI}$ increase rate during pregnancy was $17.5 \pm 9.5 \%$ (min 1\%-max $51.4 \%$ ). Mean blood loss was $57.3 \pm 43.9 \mathrm{ml}$ in the $3 \mathrm{rd}$ stage of labor and 113. $2 \pm 76.9$ $\mathrm{ml}$ in the postpartum first hour. Two women $(0.5 \%)$ had blood loss $>500 \mathrm{ml}$.

\begin{tabular}{|c|c|}
\hline \multicolumn{2}{|l|}{ Charactersitics } \\
\hline Age (year) & $26.2 \pm 5.1$ \\
\hline Gravidity & $2.3 \pm 1.3$ \\
\hline Parity & $1.0 \pm 1.0$ \\
\hline Nulliparity & $149(36.3 \%)$ \\
\hline $\mathrm{BMI}_{1}\left(\mathrm{~kg} / \mathrm{m}^{2}\right)$ & $24.4 \pm 4.2$ \\
\hline $\mathrm{BMI}_{2}\left(\mathrm{~kg} / \mathrm{m}^{2}\right)$ & $28.5 \pm 4.2$ \\
\hline BMI increase rate $(\%)$ & $17.5 \pm 9.5$ \\
\hline Previous PPH & $4(1 \%)$ \\
\hline History of anticoagulant use & $1(0.2 \%)$ \\
\hline PROM & $73(17.8 \%)$ \\
\hline Labor augmentation & $83(20.2 \%)$ \\
\hline \multicolumn{2}{|l|}{ Gestational age (weeks) } \\
\hline $37-38$ & $56(13.6 \%)$ \\
\hline $38-39$ & $81(19.7 \%)$ \\
\hline $39-40$ & $125(30.4 \%)$ \\
\hline $40-41$ & $114(27.7 \%)$ \\
\hline$>41$ & $35(8.5 \%)$ \\
\hline Duration of 1 st stage (min) & $263.4 \pm 151.4$ \\
\hline Duration of 2nd stage (min) & $27.6 \pm 26.1$ \\
\hline Duration of 3rd stage (min) & $9.6 \pm 5.9$ \\
\hline Blood loss in 3rd stage (ml) & $57.3 \pm 43.9$ \\
\hline Blood loss in postpartum 1st hour (ml) & 113. $2 \pm 76.9$ \\
\hline$\geq 500 \mathrm{ml}$ blood loss in postpartum 1st hour & $2(0.5 \%)$ \\
\hline Episiotomy & $286(69.6 \%)$ \\
\hline Laceration & $73(17.8 \%)$ \\
\hline Perineal & $48(11.7 \%)$ \\
\hline Vaginal & $24(5.8 \%)$ \\
\hline Cervical & $1(0.2 \%)$ \\
\hline Retained placenta & $2(0.5 \%)$ \\
\hline Newborn birthweight (gr) & $3275.2 \pm 402.6$ \\
\hline PrepartumHb (gr/dl) & $11.9 \pm 1.4$ \\
\hline Postpartum Hb (gr/dl) & $11.1 \pm 1.4$ \\
\hline Transfusion need & $5(1.2 \%)$ \\
\hline Erytrocyte transfusion & $5(1.2 \%)$ \\
\hline FFP transfusion & $2(0.5 \%)$ \\
\hline Platelet transfusion & - \\
\hline Hospital stay (day) & $1.2 \pm 0.4$ \\
\hline \multicolumn{2}{|c|}{$\begin{array}{l}\text { BMI, body mass index; BMI1, pre-pregnancy BMI; BMI2, BMI at birth; } \mathrm{PPH} \text {, postpartum hemorrhage; } \\
\text { PROM, premature rupture of membrane; FFP, Fresh frozen plasma; } \\
\text { Data are mean } \pm \text { SD, and number (\%) }\end{array}$} \\
\hline
\end{tabular}

No correlation was found between the blood loss in the 3rd stage of labor and $\mathrm{BMI}_{1}(r=0.015), \mathrm{BMI}_{2}(r=0.030)$, and increased rate of BMI during pregnancy $(r=0.006)$. There was also no significant correlation between the amount of blood loss in the postpartum first hour and $\mathrm{BMI}_{1}(r=-0.026)$, $\mathrm{BMI}_{2}(\mathrm{r}=-0.003)$, and increased rate of BMI during pregnancy $(r=0.037)$. Similarly, the amount of blood loss in the postpartum first hour and duration of the 1st ( $r=0.092), 2 n d(r=0.079)$, and 3rd $(r=0.044)$ stages of labor were not correlated.

As shown in Table 2, nulliparity, history of postpartum hemorrhage in previous pregnancies, and presence of episiotomy were found to be the other risk factors increasing postpartum blood loss in both the 3rd stage of labor and postpartum first hour. Episiotomy rates were $92.6 \%$ and $56.5 \%$ in nulliparous and multiparous women, respectively $(p<0.001)$. Amount of blood loss in the postpartum first hour was higher in women with premature rupture of membranes (130.1 \pm 104.5 vs. $109.6 \pm 69.3, p=0.047$ ).

\begin{tabular}{|c|c|c|c|c|}
\hline Characteristics & $\begin{array}{l}\text { Blood loss in } \\
\text { third stage of } \\
\text { labor }(\mathrm{ml})\end{array}$ & P value & $\begin{array}{l}\text { Blood loss in } \\
\text { postpartum } \\
\text { first hour }(\mathrm{ml})\end{array}$ & P value \\
\hline Age (year)* & & 0.250 & & 0.343 \\
\hline$\geq 35$ & $50(5-350)$ & & $100(20-750)$ & \\
\hline$<35$ & $50(10-200)$ & & $95(20-280)$ & \\
\hline Nulliparity† & & 0.015 & & 0.002 \\
\hline Nulliparous & $64.4 \pm 48.9$ & & $128.9 \pm 75.9$ & \\
\hline Multiparous & $53.6 \pm 40.3$ & & $103.9 \pm 76.3$ & \\
\hline $\mathrm{BMI} 1+$ & & 0.799 & & 0.451 \\
\hline$\geq 30 \mathrm{~kg} / \mathrm{m}^{2}$ & $55.9 \pm 29.7$ & & $105.1 \pm 50.0$ & \\
\hline$<30 \mathrm{~kg} / \mathrm{m}^{2}$ & $57.7 \pm 45.4$ & & $114.3 \pm 79.9$ & \\
\hline $\mathrm{BMI} 2+$ & & 0.532 & & 0.898 \\
\hline$\geq 30 \mathrm{~kg} / \mathrm{m}^{2}$ & $59.4 \pm 48.1$ & & $113.9 \pm 76.3$ & \\
\hline$<30 \mathrm{~kg} / \mathrm{m}^{2}$ & $56.5 \pm 41.6$ & & $112.9 \pm 77.5$ & \\
\hline BMI increase ratet & & 0.520 & & 0.711 \\
\hline$\geq 25 \%$ & $54.6 \pm 54.1$ & & $110.2 \pm 78.6$ & \\
\hline$<25 \%$ & $58.2 \pm 41.2$ & & $113.9 \pm 76.7$ & \\
\hline Previous PPH† & & $<0.001$ & & $<0.001$ \\
\hline Present & $157.5 \pm 149.1$ & & $250.0 \pm 212.1$ & \\
\hline Absent & $56.5 \pm 40.9$ & & $111.8 \pm 73.7$ & \\
\hline PROM† & & 0.053 & & 0.047 \\
\hline Present & $66.5 \pm 53.3$ & & $130.1 \pm 104.5$ & \\
\hline Absent & $55.6 \pm 41.4$ & & $109.6 \pm 69.3$ & \\
\hline Labor augmentationt & & 0.389 & & 0.375 \\
\hline Present & $61.2 \pm 39.6$ & & $119.9 \pm 65.8$ & \\
\hline Absent & $56.6 \pm 44.9$ & & $11.4 \pm 79.7$ & \\
\hline Gestational age† & & 0.475 & & 0.340 \\
\hline$\geq 41$ weeks & $62.6 \pm 46.9$ & & $125.3 \pm 77.6$ & \\
\hline$<41$ weeks & $57.0 \pm 43.6$ & & $112.1 \pm 76.9$ & \\
\hline Episiotomy† & & 0.001 & & $<0.001$ \\
\hline Present & $62.2 \pm 47.8$ & & $123.2 \pm 83.5$ & \\
\hline Absent & $46.8 \pm 30.9$ & & $91.1 \pm 53.9$ & \\
\hline Lacerationt & & 0.344 & & 0.302 \\
\hline Present & $53.1 \pm 36.6$ & & $104.6 \pm 65.4$ & \\
\hline Absent & $58.5 \pm 45.3$ & & $115.1 \pm 79.2$ & \\
\hline Prepartum Hb* & & 0.756 & & 0.301 \\
\hline$<10 \mathrm{gr} / \mathrm{dl}$ & $50(10-200)$ & & $100(25-400)$ & \\
\hline$\geq 10 \mathrm{gr} / \mathrm{dl}$ & $50(5-350)$ & & $100(20-750)$ & \\
\hline \multicolumn{5}{|c|}{$\begin{array}{l}\text { BMI, body mass index; BMI1, pre-pregnancy BMI; BMI2, BMI at birth; PPH, postpartum hemorrhage; } \\
\text { PROM, premature rupture of membranes } \\
\text { Data are mean } \pm \text { SD and median (min-max). } \\
\text { *Mann-Whitney U test was used. } \\
\text { tIndependent samples T test was used. }\end{array}$} \\
\hline
\end{tabular}




\section{DISCUSSION}

Although obesity is reported to be a risk factor for postpartum hemorrhage, the study result did not show any association between the increase in BMl during pregnancy and the amount of postpartum blood loss in low-risk pregnancies. Also there was no effect of pre-pregnancy BMI and BMI at birth on postpartum hemorrhage. Nulliparity, history of postpartum hemorrhage in previous pregnancy, episiotomy, and premature rupture of membranes were the other risk factors increasing postpartum blood loss in the study population.

In our series, prevalence of postpartum hemorrhage at or beyond $500 \mathrm{ml}$ was $0.5 \%$. This rate is well below the prevalence reported previously. ${ }^{[15,16]}$ A $3 \%$ incidence of postpartum hemorrhage after vaginal delivery in 31,055 women was reported in a multicenter study. ${ }^{[14]}$ Carrolli et al. ${ }^{[16]}$ reported that the global prevalence of postpartum hemorrhage $(\geq 500$ $\mathrm{ml}$ blood loss) and severe postpartum hemorrhage ( $\geq 1000$ $\mathrm{ml}$ blood loss) are $6 \%$ and $1.86 \%$ in all deliveries, respectively. The reason for this inconsistency in the literature may be the design of our study. Our study population included lowrisk pregnancies and blood loss in the postpartum first hour only was evaluated. Whereas women with well-known risk factors for postpartum hemorrhage such as hypertension, preeclampsia, diabetes mellitus, placenta previa, and so on were included in previous studies and postpartum blood loss within 24 hours was taken into account for determining the prevalence of postpartum hemorrhage.

Unlike previous publications, we did not find an association between the postpartum blood loss and BMI either prepregnancy or at birth. Recent studies reported that obesity is a risk factor for postpartum hemorrhage. ${ }^{[1,8,17,18]}$ The study population of these reports included a combination of lowand high-risk patients. Wetta et al. ${ }^{[1]}$ reported that obesity is a risk factor for postpartum hemorrhage as well as multiple gestation, hydramnios, preeclampsia, and chorioamnionitis. In a population-based cohort study, the postpartum hemorrhage risk (bleeding $>1000 \mathrm{ml}$ ) after vaginal delivery was $5.2 \%$ in women with $\mathrm{BMI} \geq 40 \mathrm{~kg} / \mathrm{m}^{2}$, whereas this incidence was $4.4 \%$ in normal weight women. ${ }^{[10]}$ Our study population included only low-risk pregnancies and vaginal deliveries to eliminate possible confounding factors. Another reason for the presented results may be the low number of obese women in the study population. A total of $47(11.5 \%)$ women had a BMI between 30 and $39.9 \mathrm{~kg} / \mathrm{m} 2$ and there was no woman with $\mathrm{BMI} \geq 40 \mathrm{~kg} / \mathrm{m}^{2}$ in our cohort.

The WHO recommends an ideal gestational weight gain according to the guidelines developed by the Institute of Medicine (IOM). ${ }^{[19]}$ Previous studies demonstrate that excessive weight gain during pregnancy is associated with adverse pregnancy outcomes such as hypertension, preeclampsia, gestational diabetes, cesarean delivery, and macrosomia. ${ }^{[12,13]}$ However, the effect of gestational weight gain during pregnancy on postpartum hemorrhage has not been clarified yet. There are conflicting results in retrospective studies reporting the relationship between gestational weight gain and postpartum hemorrhage. Li et al. ${ }^{[13]}$ reported an increase of 1.3 times in the risk of postpartum hemorrhage in women with excessive weight gain greater than the IOM recommendation. On the other hand, in a study conducted by Kominiarek et al..$^{[14]}$ the effect of gestational weight gain on postpartum hemorrhage could not be demonstrated in obese women. Risk of postpartum hemorrhage was similar in Class I, II, and III obese women with excessive weight gain and normal weight gain in this report. Our study population consisted for the most part of normal weight women, and we did not find any correlation between the gestational weight gain and postpartum blood loss after vaginal delivery.

In the present study, several features previously described as risk factors for postpartum hemorrhage were also found to be associated with an increased amount of postpartum blood loss. ${ }^{[20-23]}$ The amount of blood loss was higher in nulliparous women and women with a history of postpartum hemorrhage in previous pregnancies, premature rupture of membranes, and episiotomy. Nulliparity was found to be a risk factor as reported in the literature. The higher episiotomy rate can be speculated as the cause of increased postpartum bleeding in the nulliparous women. In a study evaluating different oxytocin protocols for active management of the 3rd stage of labor, higher postpartum blood loss was reported in women who had an episiotomy. ${ }^{[23]}$ Based on these findings, as recommended in the latest Cochrane Review, selective episiotomy should be considered instead of routine use. ${ }^{[24]}$

The major strength of our study was the homogeneity of our study population. To eliminate other confounding factors, the study population included only low-risk pregnancies who gave birth vaginally. High-risk pregnancies and operative deliveries were excluded. The same labor induction and augmentation protocol were also administered in all participants. Higher severe postpartum hemorrhage rate was reported in women who underwent labor induction with lowdose oxytocin regimen than with high-dose previously. ${ }^{[25]}$ The other strength of the study is the objective measurement of the amount of postpartum blood loss by a calibrated drape as visual estimation of blood loss is often inaccurate. ${ }^{[2,27]}$ To the best of our knowledge, this study is one of the pioneering studies using the change in BMI to evaluate its association with the amount of postpartum bleeding. Observational design is a limitation of the study. Consecutive cases were collected and the number of obese cases was found to be much lower than cases with $\mathrm{BMl}<30 \mathrm{~kg} / \mathrm{m}^{2}$ during the study period. Studies including more obese women are needed to be able to generalize our results to the obese patients' groups.

\section{CONCLUSION}

There was no relationship between the amount of postpartum blood loss and the gestational weight gain in women with lowrisk pregnancy who gave birth vaginally. Nulliparity, previous history of postpartum hemorrhage, premature rupture of membranes, and episiotomy were found to be the risk factors increasing postpartum blood loss. 


\section{ETHICAL DECLARATIONS}

Ethics Committee Approval: The study was carried out with the permission of Etlik Zubeyde Hanim Women's Health Training and Research Hospital Ethical Committee (2018/16).

Informed Consent: Because the study was designed retrospectively, no written informed consent form was obtained from patients.

\section{Referee Evaluation Process: Externally peer-reviewed. \\ Conflict of Interest Statement: The authors have no conflicts of interest to declare.}

Financial Disclosure: The authors declared that this study has received no financial support.

Author Contributions: All of the authors declare that they have all participated in the design, execution, and analysis of the paper, and that they have approved the final version.

\section{REFERENCES}

1. Wetta LA, Szychowski JM, Seals S, Mancuso MS, Biggio JR, Tita AT. Risk Factors for Uterine Atony/Postpartum Hemorrhage Requiring Treatment after Vaginal Delivery. Am J Obstet Gynecol 2013;209(1):51.e1-51.e6.

2. Al-Zirqi I, Vangen S, Forsen L, Stray-Pedersen B. Prevalence and risk factors of severe obstetric haemorrhage. BJOG 2008;115(10):1265-72

3. Zwart JJ, Richters LM, Ory F, de Vries Jl, Bloemenkamp KW, van Roosmalen $J$. Severe maternal morbidity during pregnancy, delivery and puerperium in the Netherlands: A nationawide population based study of 371,000 pregnancies. BJOG 2008;115(7):842-50.

4. Lee HJ, Lee YJ, Ahn EH, et al. Risk factors for massive postpartum bleeding in pregnancies in which incomplete placenta previa are located on the posterior uterine wall. Obstet Gynecol Sci 2017;60(6):520-6.

5. Callaghan WM, Kuklina EV, Berg CJ. Trends in postpartum hemorrhage: United States, 1994- 2006. Am J Obstet Gynecol. 2010;202:353.

6. Joseph KS, Rouleau J, Kramer MS, Young DC, Liston RM, Baskett TF. Maternal Health Study Group of the Canadian Perinatal Surveillance System. Investigation of an increase in postpartum haemorrhage in Canada. BJOG 2007;114(6):751-9.

7. Fyfe EM, Thompson JM, Anderson NH, Groom KM, McCowan LM. Maternal obesity and postpartum haemorrhage after vaginal and caesarean delivery among nulliparous women at term: a retrospective cohort study. BMC Pregnancy and Childbirth. 2012;12:112

8. Enomoto K, Aoki S, Toma R, Fujiwara K, Sakamaki K, Hirahara F. Pregnancy Outcomes Based on Pre-Pregnancy Body Mass Index in Japanese Women. PLoS One 2016;11(6):e0157081.

9. WHO. Physical Status: The Use and Interpretation of Anthropometry: Report of a World Health Organization (WHO) Expert Committee. Geneva, Switzerland: World Health Organization; 1995.

10. Blomberg M. Maternal obesity and risk of postpartum hemorrhage. Obstet Gynecol. 2011;118(3):561-8.

11. World Health Organisation. Obesity and overweight. Available at https:// www.who.int/news-room/fact-sheets/detail/obesity-and-overweight. Accessed May 262019.

12. Gaillard R, Durmus B, Hofman A, Mackenbach JP, Steegers EA, Jaddoe VW. Risk factors and outcomes of maternal obesity and excessive weight gain during pregnancy. Obesity (Silver Spring) 2013;21(5):1046-55.

13. Li C, Liu Y, Zhang W. Joint and Independent Associations of Gestational Weight Gain and Pre-Pregnancy Body Mass Index with Outcomes of Pregnancy in Chinese Women: A Retrospective Cohort Study. PLoS One 2015;10(8):e0136850.
14. Kominiarek MA, Seligman NS, Dolin C, et al. Gestational Weight Gain and Obesity: Is 20 Pounds Too Much? Am J Obstet Gynecol 2013;209(3):214. e1-214.e11.

15. Blum J, Winikoff B, Raghavan S, et al. Treatment of post-partum haemorrhage with sublingual misoprostol versus oxytocin in women receiving prophylactic oxytocin: a double-blind, randomised, noninferiority trial. Lancet 2010;375(9710):217-23.

16. Carroli G, Cuesta C, Abalos E, Gulmezoglu AM. Epidemiology of postpartum haemorrhage: a systematic review. Best Pract Res Clin Obstet Gynaecol 2008;22(6):999-1012.

17. Heslehurst N, Simpson H, Ells LJ, et al. The impact of maternal BMI status on pregnancy outcomes with immediate short-term obstetric resource implications: a meta-analysis. Obes Rev 2008;9(6):635-83.

18. Sebire NJ, Jolly M, Harris JP, et al. Maternal obesity and pregnancy outcome: a study of 287,213 pregnancies in London. Int J Obes Relat Metab Disord 2001;25(8):1175-82.

19. Rasmussen KM, Yaktine AL. Weight gain during pregnancy: reexamining the guidelines. Washington, DC: National Academies Press; 2009.

20. Driessen M, Bouvier-Colle M-H, Dupont C, et al. Postpartum haemorrhage resulting from uterine atony after vaginal delivery: factors associated with severity. Obstet Gynecol 2011;117(1):21-31.

21. Bateman BT, Berman MF, Riley LE, Leffert LR. The Epidemiology of Postpartum Hemorrhage in A Large, Nationwide Sample of Deliveries. Anesth Analg. 2010; 110(5):1368-73.

22. Buzaglo N, Harlev A, Sergienko R, Sheiner E. Risk factors for early postpartum hemorrhage (PPH) in the first vaginal delivery, and obstetrical outcomes in subsequent pregnancy. J Matern Fetal Neonatal Med 2015;28(8):932-7.

23. Oguz Orhan E, Dilbaz B, Aksakal SE, Altınbas S, Erkaya S. Prospective randomized trial of oxytocin administration for active management of the third stage of labor. Int J Gynaecol Obstet 2014;127(2):175-9.

24. Jiang H, Qian X, Carroli G, Garner P. Selective versus routine use of episiotomy for vaginal birth. Cochrane Database Syst Rev. 2017 8;2:CD000081.

25. Prichard N, Lindquist A, Hiscock R, Ruff S, Tong S, Brownfoot FC. High-dose compared with low-dose oxytocin for induction of labour of nulliparous women at term. J Matern Fetal Neonatal Med. 2019;32(3):362-8. doi: 10.1080/14767058.2017.1378338.

26. Stafford I, Dildy GA, Clark SL, Belfort MA. Visually estimated and calculated blood loss in vaginal and cesarean delivery. Am J Obstet Gynecol. 2008;199(5):519.e1-7

27. Özdilek R, Dutucu N, Coşkun AM. Postpartum Kanama Miktarını Tahminde Gerçeğe Ne Kadar Yaklaşıyoruz? Sağlık Bilimleri ve Meslekleri Dergisi. 2019; 6(1):84-90. 